Original Article

\title{
Cross-genera amplification and identification of Colpodella sp. with Cryptosporidium primers in fecal samples of zoo felids from northeast China
}

\author{
Amplificação cruzada de gêneros e identificação de Colpodella sp. com iniciadores de \\ Cryptosporidium em amostras fecais de zoofilia do nordeste da China
}

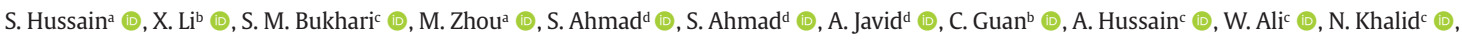

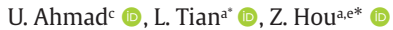

${ }^{a}$ Northeast Forestry University, College of Wildlife and Protected Area, Harbin, China

${ }^{b}$ Harbin Northern Forest Zoo, Harbin, China

cUniversity of Veterinary and Animal Sciences, Department of Wildlife and Ecology, Lahore, Pakistan

${ }^{\mathrm{d} D e p a r t m e n t ~ o f ~ E n t o m o l o g y, ~ U n i v e r s i t y ~ o f ~ t h e ~ P u n j a b, ~ L a h o r e, ~ P a k i s t a n ~}$

${ }^{\text {eChina }}$ State Forestry Administration, Key Laboratory of Wildlife Conservation, Harbin, China

\begin{abstract}
The protozoans include many intracellular human pathogens. Accurate detection of these pathogens is necessary to treat the diseases. In clinical epidemiology, molecular identification of protozoan is considered a more reliable and rapid method for identification than microscopy. Among these protozoans, Cryptosporidium considered being one of the important water-borne zoonotic pathogens and a major cause of a diarrheal disease named cryptosporidiosis in humans, domestic animals, and wild animals. This study was aimed to identify Cryptosporidium in zoo felids $(N=56)$ belonging to different zoo of China, but accidentlly Colpodella was encountered in the zoo felids sample and phylogenetic data confirmed this unexpected amplification from fecal samples using two-step nested-PCR. Phylogenetic analysis revealed the fact about the specific primers used previously by many researchers and cross-genera amplification. We came to know that genetically sequenced amplicon gives more accurate identification of species. This study suggests more investigation on Colpodella which has been neglected previously but gains the attention of researchers after identified from humans and animals and has been known to correlate with neurological symptoms in patients.
\end{abstract}

Keywords: Cryptosporidium, cross-genera, Colpodella, nested-PCR, zoo felids.

\begin{abstract}
Resumo
Os protozoários incluem muitos patógenos humanos intracelulares. A detecção acurada desses patógenos é necessária para tratar as doenças. Na epidemiologia clínica, a identificação molecular de protozoários é considerada o método de identificação mais confiável e rápido do que a microscopia. Entre esses protozoários, o Cryptosporidium é considerado um dos importantes patógenos zoonóticos transmitidos pela água e uma das principais causas de uma doença diarreica denominada criptosporidiose em humanos, animais domésticos e selvagens. Este estudo teve como objetivo identificar Cryptosporidium em zoofelídeos $(\mathrm{N}=56$ ) pertencentes a diferentes zoológicos da China, mas acidentalmente Colpodella foi encontrada na amostra de zoofelídeos e os dados filogenéticos confirmaram essa amplificação inesperada de amostras fecais usando nested-PCR em duas etapas. A análise filogenética revelou o fato sobre os primers específicos usados anteriormente por muitos pesquisadores e a amplificação entre gêneros. Ficamos sabendo que o amplicon sequenciado geneticamente fornece uma identificação mais acurada das espécies. Este estudo sugere mais investigação sobre Colpodella, que foi negligenciada anteriormente, mas ganha a atenção dos pesquisadores depois de identificada em humanos e animais e é conhecida por se correlacionar com sintomas neurológicos em pacientes.
\end{abstract}

Palavras-chave: Cryptosporidium, gênero cruzado, Colpodella, PCR aninhado, felinos do zoológico.

\section{Introduction}

Although microscopy is a traditional method for the examinations of parasites but molecular identification has become more reliable to detect protozoan parasites in domestic and wild animals. In the case of low parasitemia levels, molecular techniques have better sensitivity and specificity than that of microscopy (Maia et al., 2012; Merino et al., 2009; Moody, 2002; Rubini et al., 2005). These simple and relatively low-cost molecular techniques are

*e-mail: tianlihondz@163.com; houzhijundz@163.com

Received: January 4, 2021 - Accepted: February 18, 2021 
not time-consuming, thereby allowing for the reproducible testing of large numbers of specimens. In addition, the molecular analysis provides useful information on the diversity and genetic relationships of parasites. Most of the studies, however, estimate the prevalence of infections only on the basis of PCR testing without confirmation of sequence (Ujvari et al., 2004; Vardo et al., 2005), this could lead to false positive results and unexpected amplification of another organism.

Cryptosporidiosis is a diarrheal disease caused by Cryptosporidium (Tyzzer, 1912) species. Cryptosporidium sp. considered to be one of the important water-borne pathogens in human beings and pets, (Šlapeta, 2017) and is among the top four causes of moderate-to-severe diarrheal disease in young children in developing countries (Ryan and Hijjawi, 2015).

By applying molecular techniques, the taxonomy can incorporate genetic data as one of the parameters for validating Cryptosporidium species (Nichols et al., 2008). The molecular methods commonly used for Cryptosporidium sp. characterization is based on different types of the polymerase chain reaction (PCR)(Xiao, 2010). Such methods are usually associated with amplified fragment sequencing for verification of results (Khurana and Chaudhary, 2018; Xiao, 2010) and analysis of genetic diversity among species. Such approaches use a number of genetic markers, including, the SSU rRNA gene, the cowp gene, the $h s p 70$ gene, ITS-1 and ITS-2, the trap gene, and the gene encoding the GP60 or GP15/40 glycoproteins (Khan et al., 2018; Xiao, 2010; Xiao and Feng, 2017).

Nested-PCR has been used to amplify the18S rRNA gene of Cryptosporidium sp. with the specific primers (Ryan et al. 2003). In this study, nucleotide sequences or sequencing results demonstrated that these primers can also amplify another apicomplexan, namely Colpodella (Dujardin, 1841). That type of cross-genera amplification of apicomplexans has already been reported previously in Germany (Mendonça, 2018).

Although, Colpodella is less studied until now but the recent data from China show its pathogenic importance (Jiang et al., 2018; Yuan et al., 2012).

\section{Materials and Methods}

\subsection{Sample collection:}

Fresh fecal samples $(n=56)$ of different zoo felines (Siberian tiger $n=26$, White tiger $n=07$, Bengal tiger $n=06$, African tiger $n=06$, White lion $n=05$, Lynx $n=05$, Jaguar $\mathrm{n}=01$ ) were collected from Harbin Zoo, China. These fresh specimens were collected in the plastic bags directly from the ground and brought to the laboratory to store at $4{ }^{\circ} \mathrm{C}$ in the refrigerator. Isolation of ocysts was done within 24 hours by using the previously described discontinuous sucrose gradient method by Arrowood and Sterling (1987).

\subsection{DNA Extraction:}

QIAmp DNA Stool Kit (QIAGEN, Hilden, Germany) was used to extract DNA from $200 \mathrm{ml}$ ocysts instead of feces. In order to enhance DNA concentration, the final elution volume was adjusted to $80 \mu \mathrm{l}$ of AE buffer. Until PCR analysis, all DNA samples were stored at $-20{ }^{\circ} \mathrm{C}$.

\subsection{PCR Amplification:}

For the amplification of 18S rRNA, SEDI G thermal cycler (Wealtec Corp. Japan) was used for two-step nested-PCR. For the primary PCR, the forward primer 18SiCF2 (5-GACATTCATTTTCTGACC-3) and the reverse primer 18SiCR2 (5-CTGAAGGAGGAACAACC-3) were used to amplify a PCR product of $763 \mathrm{bp}$. A total of $25 \mu \mathrm{l}$ reaction mixture for primary PCR consisted of ExTaq premix (Takara Bio Group, Japan), $1 \mu \mathrm{M}$ of each primer and $3 \mu \mathrm{l}$ DNA. Cycling condition started with an initial cycle of denaturation at $94{ }^{\circ} \mathrm{C}$ for 5 minutes followed by $45 \mathrm{cycles}\left(94^{\circ} \mathrm{C}-30 \mathrm{~s}, 58^{\circ} \mathrm{C}-30 \mathrm{~s}, 72^{\circ} \mathrm{C}-30 \mathrm{~s}\right)$, and the final extension of $72^{\circ} \mathrm{C}$ for 10 minutes as previously described (Ryan et al., 2003). For the secondary PCR, forward primer 18SiCF1 (5-CCTATCAGCTTTAGACGGTAGG-3) and reverse primer 18SiCR1 (5-TCTAAGAATTTCACCTCTGACTG-3) were used to amplify a fragment of $587 \mathrm{bp}$. Optimum PCR cycling conditions were adjusted for both steps. Agarose gel (1\%) with GoldView ${ }^{\mathrm{TM}}$ (Solarbio, China) was used to electrophorese the secondary PCR products.

\subsection{Sequencing and data analyzing:}

Positive Secondary PCR products on the gel were excised and purified using the AxyPrep DNA Gel Extraction Kit (Axygen, USA). Secondary PCR amplification with the same cycling conditions and primers was revised by using purified DNA as a template. PCR products were Sequenced from the Comate Biosciences Co., Ltd. (Changchun, China). DNAMAN and the Basic Local Alignment Search Tool (BLAST) were used to perform similarity analysis of sequenced data.

\subsection{Sequence and phylogenetic analysis:}

The sequenced data obtained from the company were trimmed by using BioEdit 7.2.0. Sequence of Cryptosporidium sp. and Colpodella sp. showed many similarities. All the obtained sequences were submitted to the GenBank database for unique code (accession number). Phylogenetic tree was generated with obtained sequences and reference data of NCBI by using the neighbor-joining method.

\section{Results}

\subsection{Analysis of PCR amplification of Cryptosporidium sp. and Colpodella sp.}

The analysis of the sequences showed a cross-genera amplification phenomenon as these primers not just amplified Cryptosporidium sp. (17/56) but Colpodella sp. (07/56) too. Amplicon sizes were 585 bp and 583 bp for Cryptosporidium sp. and Colpodella sp. respectively.

\subsection{Amplification of Cryptosporidium $s p$.}

See Figure 1. 


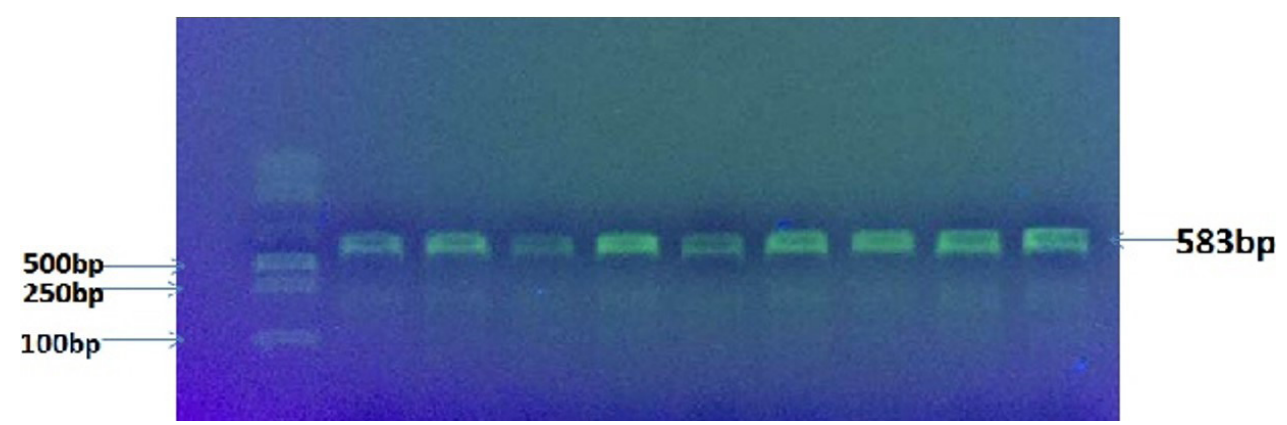

Figure 1. Amplification of $18 \mathrm{~S}$ rRNA gene from Colpodella sp.

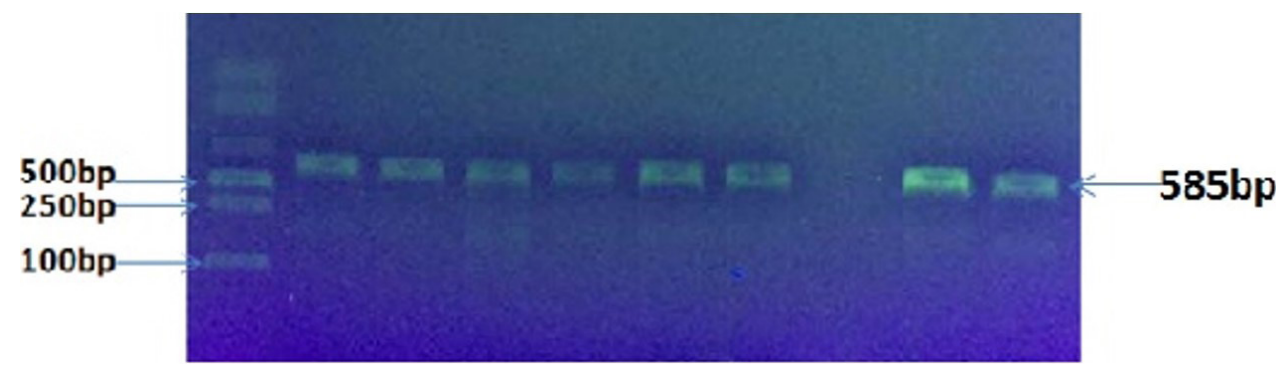

Figure 2. Amplification of $18 \mathrm{~S}$ rRNA gene from Cryptosporidium spp.

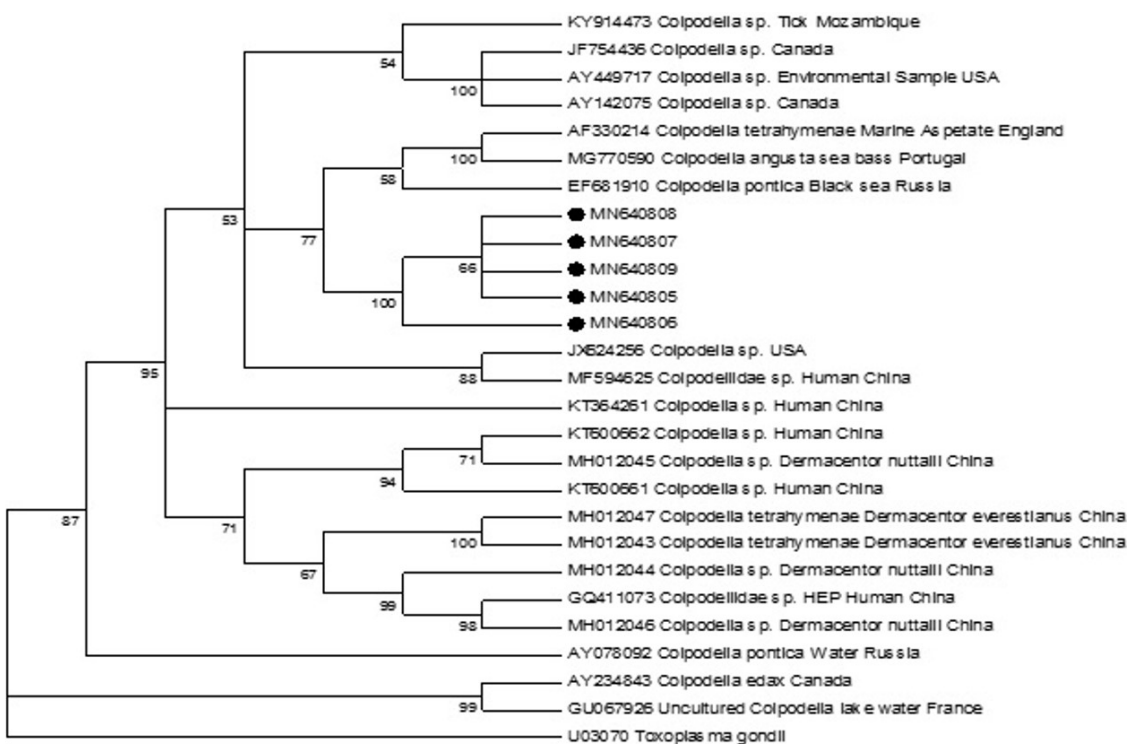

Figure 3. Phylogenetic tree of sequences of $18 \mathrm{~S}$ rRNA gene using the Neighbor-Joining method. Black and bold circled sequences belong to this study. Remaing sequences retrieved from GenBank.

\subsection{Amplification of Colpodella sp.}

See Figure 2.

\subsection{Phylogenetic and comparative analysis}

All 17 Cryptosporidium sp. sequences were alike Cryptosporidium sp. NEV10 (accession no. (JN245625) While On the basis of 18S rRNA gene, a tree was constructed to explain the phylogenetic relationship of Colpodella sp. see Figure 3 and Figure 4.

\section{Discussion}

The PCR primers used in this study were previously known to have the ability to amplify a segment of the Cryptosporidium sp. 18S rRNA gene (Alkhaled, 2017; Ayinmode et al., 2018; Ayinmode et al., 2017; Camargo et al., 2018; Lucio et al., 2016). But our results revealed that Colpodella sp. could also be amplified by using same set of primers. Cryptosporidium belongs to apicomplexan parasites that have evolved from algal ancestors and their closest relatives are 


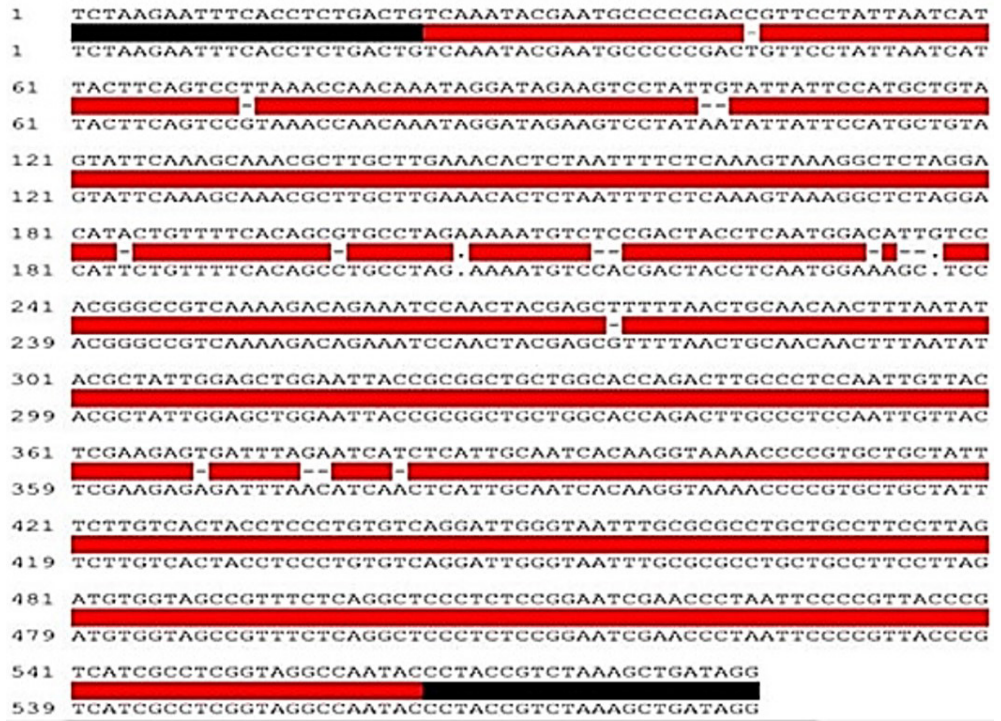

Figure 4. Comparative analysis of the sequences of Cryptosporidium sp. and Colpodella sp. Upper line: Cryptosporidium sp. from 1 to 585; Lower line: Colpodella sp. from 1 to 583; Ratio of identity = 97.26\% (567/583); gap = 0.34\% (2/585); Black line = Forward and Reverse Primers; Red line = similar nucleotides; ' - ' = dissimilar nucleotides; ' . ' = Gaps.

parasitic flagellates (colpodellides) and algae (chromerids) (McFadden et al., 1996; Moore et al., 2008).

Previously, Copodella have been identified from blood, ticks and soil samples (Han et al., 2018; Jiang et al., 2018; Matsimbe et al., 2017; Olmo et al., 2011; Yuan et al., 2012) but as per our best knowledge, this is the first study in which Colpodella have been identified from the fecal samples of zoo felines of Northeast China. Researchers have realized the pathogenic importance of Colpodella after two case reports from China (Jiang et al., 2018; Yuan et al., 2012) where Colpodella has been found to associate with neurological symptoms and Babesia sp. like relapsing infection

Our findings are similar to the findings of the study conducted in Germany to test a cross-genera amplification of Babesia, Theileria specific primer. Three other apicomplexans including Toxoplasma, Hepatozoon, and Hammondia were also successfully amplified by the same set of primers (Mendonça, 2018). Another unexpected amplification of Proteromonas was noticed when apicomplexan parasites were routinely screened using 18S rRNA gene (Maia et al., 2012).

Genotyping is very important to get reliable results (Papini and Verin, 2019) just like the study undertaken where sequencing revealed about cross-genera amplification. Comparative analysis of the received sequences in Figure 4 showed that both Cryptosporidium sp. and Colpodella sp. contained secondary pcr primers (18SiCF1 and 18SiCR1). The ratio of identity was $97.26 \%$ and only two gaps were found in nucleotide sequence. Phylogenetic tree was constructed for the better understanding among generic phylogenetic relationships.

\section{Conclusion}

In the present study, Cross-genera amplification and unexpected identification of Colpodella from the fecal samples of zoo felines has been reported first time. Analysis of the sequences of Cryptosporidium sp. and Colpodella sp. revealed $97.26 \%$ identity. It is concluded from the study that sequencing is necessary to confirm the parasitic infection so that we can avoid the false-positive results or unexpected amplification of less common parasites. However, new primers should be explored for more positive, accurate and error free results.

\subsection{Accession Numbers}

Sequences were submitted to GenBank under accession number of: Colpodella sp. MN640805, MN640806, MN640807, MN640808, MN640809; and Cryptosporidium sp. MN640812, MN640813, MN640814, MN640815, MN640816.

\section{Abbreviations}

SSU rRNA gene: Small Subunit rRNA gene COWP gene: Cryptosporidium Oocyst Wall Protein gene hsp70 gene: Heat Shock Proteins gene

ITS: Internal Transcribed Spacer

trap: Triiodothyronine Receptor Auxiliary Protein

PCR: polymerase chain reaction

DNA: deoxyribonucleic acid

\section{Acknowledgements}

This research was funded by the National Key Research and Development Program (project 2017YFD0501702), Fundamental Research Funds for the Central Universities (2572018BE07) and Surveillance of Wildlife Diseases from the State Forestry Administration of China. 


\section{Reference}

ALKHALED, M.J., 2017. Molecular characterization of Cryptosporidium sp. in sheep and goat in Al-Qadisiyah province/Iraq. Iraqi Journal of Veterinary Sciences, vol. 41, no. 2, pp. 31-37.

ARROWOOD, M.J. and STERLING, C.R., 1987. Isolation of Cryptosporidium oocysts and sporozoites using discontinuous sucrose and isopycnic Percoll gradients. The Journal of Parasitology, vol. 73, no. 2, pp. 314-319. http://dx.doi.org/10.2307/3282084. PMid:3585626.

AYINMODE, A.B., OGBONNA, N.F. and WIDMER, G., 2017. Detection and molecular identification of Cryptosporidium species in laboratory rats (Rattus norvegicus) in Ibadan, Nigeria. Annals of Parasitology, vol. 63, no. 2, pp. 105-109. PMid:28802280.

AYINMODE, A.B., OLIVEIRA, B., OBEBE, O., DADA-ADGEBOLA, H.O., AYEDE, A.I. and WIDMER, G., 2018. Genotypic characterization of Cryptosporidium species in humans and peri-domestic animals in Ekiti and Oyo States, Nigeria. The Journal of Parasitology, vol. 104, no. 6, pp. 639-644. http://dx.doi.org/10.1645/17-74. PMid:30207199.

CAMARGO, V.S., SANTANA, B.N., FERRARI, E.D., NAKAMURA, A.A., NAGATA, W.B., NARDI, A.R.M. and MEIRELES, M.V., 2018. Detection and molecular characterization of Cryptosporidium sp. in captive canaries (Serinus canaria) using different diagnostic methods. Revista Brasileira de Parasitologia Veterinária, vol. 27, no. 1, pp. 61-65. http://dx.doi.org/10.1590/s1984-296120180010. PMid:29641795.

LUCIO, A., MERINO, FJ., MARTÍNEZ-RUIZ, R., BAILO, B., AGUILERA, M., FUENTES, I. and CARMENA, D., 2016. Molecular genotyping and sub-genotyping of Cryptosporidium sp. isolates from symptomatic individuals attending two major public hospitals in Madrid, Spain. Infection, Genetics and Evolution, vol. 37, pp. 49-56. http://dx.doi. org/10.1016/j.meegid.2015.10.026. PMid:26518912.

HAN, R., YANG, J., NIU, Q., LIU, Z., CHEN, Z., KAN, W., HU, G., LIU, G., LUO, J. and YIN, H., 2018. Molecular prevalence of spotted fever group rickettsiae in ticks from Qinghai Province, northwestern China. Infection, Genetics and Evolution, vol. 57, pp. 1-7. http:// dx.doi.org/10.1016/j.meegid.2017.10.025. PMid:29107656

JIANG, J.F., JIANG, R.R., CHANG, Q.C., ZHENG, Y.C., JIANG, B.G., SUN, Y., JIA, N., WEI, R., LIU, H.B., HUO, Q.B., WANG, H., VON FRICKEN, M.E. and CAO, W.C., 2018. Potential novel tick-borne Colpodella species parasite infection in patient with neurological symptoms. PLoS Neglected Tropical Diseases, vol. 12, no. 8, pp. e0006546. http://dx.doi.org/10.1371/journal.pntd.0006546. PMid:30071019.

KHAN, A., SHAIK, J.S. and GRIGG, M.E., 2018. Genomics and molecular epidemiology of Cryptosporidium species. Acta Tropica, vol. 184, pp. 1-14. http://dx.doi.org/10.1016/j.actatropica.2017.10.023. PMid:29111140.

KHURANA, S. and CHAUDHARY, P., 2018. Laboratory diagnosis of cryptosporidiosis. Tropical Parasitology, vol. 8, no. 1, pp. 2-7. http://dx.doi.org/10.4103/tp.TP_34_17. PMid:29930899.

MAIA, J.P., GÓMEZ-DÍAZ, E. and HARRIS, D.J., 2012. Apicomplexa primers amplify Proteromonas (Stramenopiles, Slopalinida, Proteromonadidae) in tissue and blood samples from lizards. Acta Parasitologica, vol. 57, no. 4, pp. 337-341. http://dx.doi. org/10.2478/s11686-012-0048-z. PMid:23129192.

MATSIMBE, A.M., MAGAIA, V.,SANCHES, G.S., NEVES, L., NOORMAHOMED, E., ANTUNES, S. and DOMINGOS, A., 2017. Molecular detection of pathogens in ticks infesting cattle in Nampula province, Mozambique. Experimental E'Applied Acarology, vol. 73, no. 1, pp.91102. http://dx.doi.org/10.1007/s10493-017-0155-5.PMid:28856544.

MCFADDEN, G.I., REITH, M.E., MUNHOLLAND, J. and LANG-UNNASCH, N., 1996. Plastid in human parasites. Nature, vol. 381, no. 6582, pp. 482. http://dx.doi.org/10.1038/381482a0. PMid:8632819.
MENDONÇA, P.G., 2018. Cross-genera PCR amplification of DNA from apicomplexan parasites. Journal of Arthropod-Borne Diseases, vol. 12, no. 3, pp. 321-324. PMid:30584555.

MERINO, S., VÁSQUEZ, R.A., MARTÍNEZ, J., CELIS-DIEZ, J.L., GUTIÉRREZ-JIMÉNEZ, L., IPPI, S., SÁNCHEZ-MONSALVEZ, I. and PUENTE, J.M., 2009. Molecular characterization of an ancient Hepatozoon species parasitizing the 'living fossil'marsupial 'Monito del Monte' Dromiciops gliroides from Chile. Biological Journal of the Linnean Society, vol. 98, no. 3, pp. 568-576. http:// dx.doi.org/10.1111/j.1095-8312.2009.01302.x.

MOODY, A., 2002. Rapid diagnostic tests for malaria parasites. Clinical Microbiology Reviews, vol. 15, no. 1, pp. 66-78. http:// dx.doi.org/10.1128/CMR.15.1.66-78.2002. PMid:11781267.

MOORE, R.B., OBORNÍK, M., JANOUŠKOVEC, J., CHRUDIMSKÝ, T., VANCOVÁ, M., GREEN, D.H., WRIGHT, S.W., DAVIES, N.W., BOLCH, C.J., HEIMANN, K., SLAPETA, J., HOEGH-GULDBERG, O., LOGSDON, J.M. and CARTER, D.A., 2008. A photosynthetic alveolate closely related to apicomplexan parasites. Nature, vol. 451, no. 7181, pp. 959-963. http://dx.doi.org/10.1038/ nature06635. PMid:18288187.

NICHOLS, G., FAYER, R. and XIAO, L., 2008. Cryptosporidium and cryptosporidiosis. Boca Raton: CRC Press.

OLMO, J.L., ESTEBAN, G.F. and FINLAY, B.J., 2011. New records of the ectoparasitic flagellate Colpodella gonderi on non-Colpoda ciliates. International Microbiology, vol. 14, no. 4, pp. 207-211. PMid:22569758.

PAPINI, R.A. and VERIN, R., 2019. Giardia and Cryptosporidium in red foxes (Vulpes Vulpes): screening for coproantigens in a population of central Italy and mini-review of the literature. Macedonian Veterinary Review, vol. 42, no. 1, pp. 101-106. http:// dx.doi.org/10.2478/macvetrev-2019-0013.

RUBINI, A.S., PADUAN, K.S., CAVALCANTE, G.G., RIBOLLA, P.E. and O'DWYER, L.H., 2005. Molecular identification and characterization of canine Hepatozoon species from Brazil. Parasitology Research, vol. 97, no. 2, pp. 91-93. http://dx.doi. org/10.1007/s00436-005-1383-x. PMid:15948009.

RYAN, U. and HIJJAWI, N., 2015. New developments in Cryptosporidium research. International Journal for Parasitology, vol. 45, no. 6, pp. 367-373. http://dx.doi.org/10.1016/j. ijpara.2015.01.009. PMid:25769247.

RYAN, U., XIAO, L., READ, C., ZHOU, L., LAL, A.A. and PAVLASEK, I., 2003. Identification of novel Cryptosporidium genotypes from the Czech Republic. Applied and Environmental Microbiology, vol. 69, no. 7, pp. 4302-4307. http://dx.doi.org/10.1128/ AEM.69.7.4302-4307.2003. PMid:12839819.

ŠLAPETA, J., 2017. Cryptosporidium: identification and genetic typing. Current Protocols in Microbiology, vol. 44, pp. 20B.1.120B.1.17. http://dx.doi.org/10.1002/cpmc.24. PMid:28166384.

UJVARI, B., MADSEN, T. and OLSSON, M., 2004. High prevalence of Hepatozoon sp.(Apicomplexa, Hepatozoidae) infection in water pythons (Liasis fuscus) from tropical Australia. The Journal of Parasitology, vol. 90, no. 3, pp. 670-672. http://dx.doi.org/10.1645/ GE-204R. PMid:15270125.

VARDO, A.M., WARGO, A.R. and SCHALL, J., 2005. PCR detection of lizard malaria parasites: prevalence of Plasmodium infections with low-level parasitemia differs by site and season. The Journal of Parasitology, vol. 91, no. 6, pp. 1509-1511. http:// dx.doi.org/10.1645/GE-589R.1. PMid:16539045.

XIAO, L. and FENG, Y., 2017. Molecular epidemiologic tools for waterborne pathogens Cryptosporidium sp. and Giardia duodenalis. Food and Waterborne Parasitology, vol. 8-9, pp. 14-32. http://dx.doi.org/10.1016/j.fawpar.2017.09.002. PMid:32095639. 
XIAO, L., 2010. Molecular epidemiology of cryptosporidiosis: an update. Experimental Parasitology, vol. 124, no. 1, pp. 80-89. http://dx.doi.org/10.1016/j.exppara.2009.03.018. PMid:19358845.
YUAN, C.L., KEELING, P.J., KRAUSE, P.J., HORAK, A., BENT, S., ROLLEND, L. and HUA, X.G., 2012. Colpodella sp.-like parasite infection in woman, China. Emerging Infectious Diseases, vol. 18, no. 1, pp. 125127. http://dx.doi.org/10.3201/eid1801.110716. PMid:22260904. 